\title{
ODLUČIVANJE O IMOVINSKIM ODNOSIMA BRAČNIH DRUGOVA U OSTAVINSKIM POSTUPCIMA SUKLADNO UREDBI 2016/1103 O BRAČNOIMOVINSKOM REŽIMU
}

Dr. sc. Paula Poretti, docentica

Pravni fakultet Sveučilišta u Osijeku
UDK: $347.919 .1:: 061.1 \mathrm{EU}$

Ur.: 2. veljače 2017.

Pr.: 6. veljače 2017.

Pregledni znanstveni rad

\begin{abstract}
Sažetak
Donošenjem Uredbe (EU) Vijeća 2016/1103 od 24. lipnja 2016. o provedbi pojačane suradnje u području nadležnosti, mjerodavnog prava te priznavanja $i$ izvršenja odluka u stvarima bračnoimovinskih režima (dalje: Uredbe 2016/1103) u 18 država članica koje sudjeluju u pojačanoj suradnji primjenom zajedničkih pravila olakšat će se odlučivanje u stvarima bračnoimovinskog režima s prekograničnim elementom. Ujedno se očekuje da će njezinim provođenjem u državama članicama biti olakšana primjena ostalih europskih instrumenata iz područja europskoga obiteljskog prava upostupcima razvoda brakai ostavinskim postupcima. U radu će se prikazati pravila Uredbe 2016/1103 o nadležnosti $i$ mjerodavnom pravu u postupcima u kojima se odlučuje o bračnoimovinskom režimu bračnih drugova. Analizirat će se primjena pravila Uredbe 2016/1103 o nadležnosti i mjerodavnom pravu u ostavinskim postupcima s prekograničnim elementom u kojima se primjenjuje Uredba 650/2012 o nasljeđivanju. Ukazat će se na potencijalna sporna mjesta i otvorena pitanja pri tumačenju pravila Uredbe 2016/1103 koja bi mogla izazvati dvojbe i nedorečenosti za sud ili javne bilježnike u razrješavanju pitanja imovinskih odnosa u postupcima u kojemu odlučuju o nasljeđivanju. Zaključno će se predložiti moguća rješenja kojima bi se mogle otkloniti poteškoće i nedostatci u praktičnoj primjeni Uredbe 2016/1103.
\end{abstract}

Ključne riječi: nasljeđivanje, bračnoimovinski režim, nadležnost, mjerodavno pravo, bračni drug.

\section{UVOD}

Pitanje podjele bračne stečevine redovito se javlja u postupcima koji se tiču okončanja braka, bilo zbog razvoda ili smrti jednog od bračnih drugova. Nerijetko, predstavlja jedno od složenijih pitanja o kojemu treba odlučiti sud ili drugo tijelo nadležno za postupanje u konkretnom sporu. Ako se to pitanje pojavi u predmetu s prekograničnim elementom, okolnost da nadležno tijelo, prije negoli započne postupanje ima utvrditi je li nadležno, a potom i koje pravo treba primijeniti kao 
mjerodavno, čini postupanje u predmetu još zahtjevnijim negoli u nacionalnom predmetu te pred sud ili drugo nadležno tijelo koje postupa postavlja dodatne izazove. Naime, na razini Europske unije (dalje: EU) zbog nepostojanja europskog instrumenta iz područja pravosudne suradnje u građanskim i trgovačkim stvarima koji bi pojednostavio rješavanje pitanja nadležnosti, mjerodavnog prava te priznanja i izvršenja odluka u stvarima bračnoimovinskih režima u predmetu s prekograničnim elementom, primjenjuju se pravila sukoba zakona za rješavanje tih pitanja. Kako su pravila sukoba zakona nacionalna pravila pojedinih država za rješavanje pitanja nadležnosti te priznanja i izvršenja stranih odluka u stvarima bračnoimovinskih režima, nerijetko, ona predstavljaju prepreku slobodnom kretanju osoba, osobito u slučajevima kolizije među pravilima različitih država, koja otežava pravnim praktičarima postupanje, a bračnim drugovima upravljanje odnosno podjelu zajedničke imovine.

Za usporedbu, postupanje hrvatskih javnih bilježnika kao povjerenika suda i sudova u predmetima nasljeđivanja s prekograničnim elementom bitno je olakšano donošenjem Uredbe (EU) br. 650/2012 Europskog parlamenta i Vijeća od 4. srpnja 2012. o nadležnosti, mjerodavnom pravu, priznavanju i izvršavanju odluka i prihvaćanju i izvršavanju javnih isprava u nasljednim stvarima i o uspostavi Europske potvrde o nasljeđivanju $^{1}$ (dalje: Uredba 650/2012 o nasljeđivanju), kojom su predviđena pravila za utvrđivanje nadležnosti, mjerodavnog prava te priznanja i izvršenja odluka o nasljeđivanju između država članica. Budući da je u državama članicama, uključujući i Republiku Hrvatsku (dalje: RH), Uredba 650/2012 o nasljeđivanju odnedavno u primjeni, u hrvatskom je pravnom sustavu za sada primijenjena u malom broju predmeta. Ipak, dosadašnja praksa pokazuje da, unatoč pojedinim nedorečenostima koje otvaraju određene dvojbe pri tumačenju i primjeni odredaba Uredbe 650/2012 o nasljeđivanju te Zakona o provedbi Uredbe (EU) br. 650/2012 Europskog parlamenta i Vijeća od 4. srpnja 2012. o nadležnosti, mjerodavnom pravu, priznavanju i izvršavanju odluka i prihvaćanju i izvršavanju javnih isprava u nasljednim stvarima i o uspostavi Europske potvrde o nasljeđivanju² (dalje: Zakon o provedbi Uredbe 650/2012 o nasljeđivanju), ona predstavlja značajan instrument koji olakšava odlučivanje o nasljeđivanju s prekograničnim elementom.

Uredba 650/2012 o nasljeđivanju propisuje pravila o nadležnosti i mjerodavnom pravu te priznanju i ovrsi strane odluke u državi članici. Kao temeljni kriterij Uredba 650/2012 o nasljeđivanju primjenjuje kriterij uobičajenog boravišta ostavitelja, dok se državljanstvo pojavljuje kao podredni kriterij. Jedan od ciljeva kojega se Uredbom 650/2012 o nasljeđivanju željelo postići jest da sud koji je nadležan sukladno

1 Uredba (EU) br. 650/2012 Europskog parlamenta i Vijeća od 4. srpnja 2012. o nadležnosti, mjerodavnom pravu, priznavanju i izvršavanju odluka i prihvaćanju i izvršavanju javnih isprava u nasljednim stvarima i o uspostavi Europske potvrde o nasljeđivanju, Službeni list EU L 201, 27.7.2012, str. 107-134. Posebno izdanje na hrvatskom jeziku, poglavlje 19, vol. 010, str. $296-323$.

2 Zakon o provedbi Uredbe (EU) br. 650/2012 Europskog parlamenta i Vijeća od 4. srpnja 2012. o nadležnosti, mjerodavnom pravu, priznavanju i izvršavanju odluka i prihvaćanju i izvršavanju javnih isprava u nasljednim stvarima i o uspostavi Europske potvrde o nasljeđivanju, NN, br. $152 / 14$. 
pravilima Uredbe 650/2012 o nasljeđivanju, u predmetu s prekograničnim elementom primjenjuje vlastito pravo. Uz to, naglašena je autonomija volje ostavitelja da izabere kao mjerodavno pravo države svog državljanstva. Pritom, nasljednicima je omogućeno sporazumijevanje o nadležnosti suda države članice čije je pravo ostavitelj izabrao kao mjerodavno pravo, upravo kako bi se ostvarila ideja o postupanju nadležnog suda prema pravu vlastite države članice.

Za razliku od javnih bilježnika, koji kod postupanja u stvarima nasljeđivanja $\mathrm{s}$ prekograničnim elementom u utvrđivanju nadležnosti i mjerodavnog prava primjenjuju isključivo Uredbu 650/2012 o nasljeđivanju, sudovi u vođenju postupka za razvod braka s prekograničnim elementom primjenjuju Uredbu Vijeća (EZ) br. 2201/2003 od 27. studenoga 2003. o nadležnosti, priznavanju i izvršenju sudskih odluka u bračnim sporovima i u stvarima povezanim s roditeljskom odgovornošću, kojom se stavlja izvan snage Uredba (EZ) br. 1347/2000 (dalje: Uredba Brisel II bis) kako bi utvrdili nadležnost u konkretnom predmetu, dok mjerodavno pravo određuju uz primjenu odredaba Uredbe Vijeća (EU) br. 1259/2010 od 20. prosinca 2010. o provedbi pojačane suradnje u području prava primjenjivog na razvod braka i zakonsku rastavu, (dalje: Uredba Rim III). ${ }^{4}$ Podjednako kao i Uredba 650/2012 o nasljeđivanju, Uredba Brisel II bis primjenjuje kriterij uobičajenog boravišta jedne ili obiju stranaka, a strankama je dopušteno i sporazumjeti se o nadležnosti, pri čemu kao nadležan mogu izabrati sud svoga uobičajenog boravišta. Uredba Rim III predviđa niz pravila prema kojima se pomoću kriterija uobičajenog boravišta određuje pravo koje se ima primijeniti ako izostane sporazum stranaka o mjerodavnom pravu u postupku razvoda braka. Isto tako, strankama je ostavljena i mogućnost izbora mjerodavnog prava, uz primjenu kriterija uobičajenog boravišta ili državljanstva jedne ili obiju stranaka, kao najbližih poveznica.

U tom smislu, za postupke u kojima će sud odlučivati o razvodu braka ili javni bilježnik odnosno sud o nasljeđivanju s prekograničnim elementom u RH, bit će važno usvajanje Uredbe (EU) Vijeća 2016/1103 od 24. lipnja 2016. o provedbi pojačane suradnje u području nadležnosti, mjerodavnog prava te priznavanja i izvršenja odluka u stvarima bračnoimovinskih režima ${ }^{5}$ (dalje: Uredba 2016/1103). Naime, očekuje se da će postupanje sudova i javnih bilježnika biti olakšano u postupcima razvoda braka ili nasljeđivanja u kojima se javlja pitanje vezano uz podjelu bračne stečevine bračnih drugova, s obzirom na to da će iz Uredbe 2016/1103 biti jasno koji bi sud države članice trebao biti nadležan u postupku i koje se pravo ima primijeniti kao mjerodavno.

3 Uredba Vijeća (EZ) br. 2201/2003 od 27. studenoga 2003. o nadležnosti, priznavanju i izvršenju sudskih odluka u bračnim sporovima i u stvarima povezanim s roditeljskom odgovornošću, kojom se stavlja izvan snage Uredba (EZ) br. 1347/2000, Službeni list L 338, 23/12/2003, str. $0001-0029$.

4 Uredba Vijeća (EU) br. 1259/2010 od 20. prosinca 2010. o provedbi pojačane suradnje u području prava primjenljivog na razvod braka i zakonsku rastavu, Službeni list, L 343, 29.12.2010., str. 10.

5 Uredba (EU) Vijeća 2016/1103 od 24. lipnja 2016. o provedbi pojačane suradnje u području nadležnosti, mjerodavnog prava te priznavanja i izvršenja odluka u stvarima bračnoimovinskih režima, Službeni list, L 183/1 od 8. srpnja 2016. 
Obrazloženje uz Prijedlog Uredbe Vijeća o nadležnosti, o mjerodavnom pravu te priznavanju i izvršenju odluka u stvarima bračnoimovinskih režima ${ }^{6}$ (dalje: Prijedlog Uredbe 2016/1103), uz pregled relevantnih dokumenata koji su prethodili njegovoj izradi, donosi i naznake elemenata politike EU-a koja je doprinijela usvajanju unificiranih pravila koja se odnose na postupke u kojima se odlučuje o imovinskim odnosima u prekograničnim odnosima na europskoj razini, što olakšava tumačenje i razumijevanje pojedinih rješenja čija bi se primjena trebala osigurati provedbom Uredbe 2016/1103 u dijelu država članica. Naime, na sastanku održanom 3. prosinca 2015. Vijeće je ocijenilo je da nisu postignuti uvjeti za uspostavljanje suradnje između svih država članica u pogledu bračnoimovinskih režima i imovinskih posljedica registriranih partnerstava. ${ }^{7}$ Ipak, 18 država članica izrazilo je spremnost za uspostavljanje pojačane suradnje u području imovinskih režima međunarodnih parova. ${ }^{8}$ S tim u vezi, Vijeće je 9. lipnja 2016. donijelo Odluku (EU) 2016/954 o odobrenju pojačane suradnje između tih 18 država članica. ${ }^{9}$ Premda bi se Uredba od 29. siječnja 2019. trebala izravno primjenjivati samo u državama članicama koje sudjeluju u pojačanoj suradnji, to ne priječi druge države da se nakon njezinog uspostavljanja ili bilo kojem naknadnom trenutku odluče sudjelovati u suradnji, pri čemu će se u tim državama članicama primjenjivati od trenutka donošenja odluke.

Cilj Uredbe 2016/1103 je omogućiti da se u postupku odlučivanja o razvodu braka u kojemu se nadležnost suda određuje sukladno odredbama Uredbe Brisel II bis ili u postupku nasljeđivanja u kojemu se nadležnost suda određuje sukladno Uredbi 650/2012 o nasljeđivanju, pravilima o koncentraciji nadležnosti osigura da nadležni sud odlučuje i o bračnoimovinskom režimu bračnih drugova povezanim s tim predmetom. Kada se odlučuje samostalno o bračnoimovinskom režimu stranaka u postupku s prekograničnim elementom, odnosno, neovisno o postupku u kojemu se odlučuje o razvodu braka ili o nasljeđivanju, Uredba 2016/1103 predviđa hijerarhijski strukturirane kriterije za utvrđivanje nadležnosti, pri čemu je primarni kriterij uobičajeno boravište bračnih drugova u trenutku pokretanja postupka pred sudom. ${ }^{10}$

U interesu pravne sigurnosti Uredba 2016/1103 omogućuje bračnim drugovima da sukladno njezinim pravilima unaprijed znaju koje se pravo ima primijeniti u postupku u kojemu se odlučuje o njihovu bračnoimovinskom režimu. Također, bračnim drugovima ostavljena je i mogućnost izbora mjerodavnog prava koje se ima primijeniti na njihovu cjelokupnu imovinu, neovisno o tomu gdje se ona nalazi i to

6 Uredba Vijeća o provedbi pojačane suradnje u području nadležnosti, mjerodavnog prava te priznavanja i izvršenja odluka u stvarima bračnoimovinskih režima, međuinstitucijski predmet: 2016/0059 (CNS), JUST CIV 70, 30. svibnja 2016. (OR.en). Usporedi Prijedlog Uredbe Vijeća o nadležnosti, mjerodavnom pravu te priznavanju i izvršenju odluka u stvarima bračnoimovinskih režima, $\operatorname{COM}(2011) 126$.

7 Vidi Preambula (10) Uredbe 2016/1103.

8 Među državama članicama koje sudjeluju u pojačanoj suradnji u području imovinskih režima međunarodnih parova su Belgija, Grčka, Slovenija, Španjolska, Francuska, Portugal, Italija, Malta, Luxemburg, Njemačka, Republika Češka, Nizozemska, Austrija, Bugarska, Finska, Cipar.

9 Vidi Preambula (12) Uredbe 2016/1103.

10 Time Uredba također slijedi ideju Uredbe Brisel II bis i Uredbe 650/2012 o nasljeđivanju, što omogućuje ujednačenost primjene pravila za donošenje. 
prije ili za vrijeme sklapanja braka ili tijekom trajanja braka.

U radu će se prezentirati pravila Uredbe 2016/1103 o nadležnosti i mjerodavnom pravu u postupcima u kojima se odlučuje o bračnoimovinskom režimu bračnih drugova. Potom će se analizirati usklađenost pravila Uredbe 2016/1103 s pravilima Uredbe 650/2012 o nasljeđivanju. Ukazat će se na potencijalna sporna mjesta i otvorena pitanja pri tumačenju pravila Uredbe 2016/1103 koja bi mogla izazvati dvojbe i nedorečenosti za sud ili javne bilježnike u razrješavanju pitanja imovinskih odnosa u postupcima u kojima odlučuju o nasljeđivanju.

No, najprije je potrebno osvrnuti se na određivanje nekoliko pojmova koje donosi Uredba 2016/1103 o bračnoimovinskom režimu, a bitni su za razumijevanje i primjenu njezinih odredaba. U prvom redu, radi se o pojmu bračnoimovinskog režima kojega se u smislu Uredbe 2016/1103 ima razumjeti kao skup pravila koja se tiču imovinskih odnosa između bračnih drugova i u njihovim odnosima s trećim osobama, kao rezultat braka ili njegova razvrgnuća. ${ }^{11}$ Riječ je o općenitom određenju kojim se nastojalo obuhvatiti režime bračne stečevine koje poznaju države članice. Istovremeno, premda se Uredba 2016/1103 ima primjenjivati u postupcima s prekograničnim elementom u kojima se odlučuje o bračnoimovinskom režimu bračnih drugova, iz njezinog teksta to nije jasno vidljivo. Naime nigdje se u tekstu ne previđa izrijekom da se ima primjenjivati u postupcima s prekograničnim elementom. Isključivo se u preambuli (14) Uredbe 2016/1103 naznačuje da bi se u skladu s čl. 81. Ugovora o funkcioniranju Europske unije ${ }^{12}$ (dalje: UFEU) ona trebala primjenjivati u kontekstu bračnoimovinskih režima s prekograničnim implikacijama. Stoga, čini se da bi zaključak o primjeni Uredbe 2016/1103 isključivo u postupcima s prekograničnim elementom trebalo izvoditi iz okolnosti da EU crpi svoje ovlaštenje za uređivanje područja bračnoimovinskih režima bračnih drugova iz čl. 81. UFEUa. ${ }^{13}$ U tom smislu, Uredba 2016/1103 slijedi niz europskih instrumenata iz područja pravosudne suradnje kojima su propisane odredbe o nadležnosti odnosno odredbe o nadležnosti i mjerodavnom pravu, poput čl. 1. Uredbe (EU) br. 1215/2012 Europskog parlamenta i Vijeća od 12. prosinca 2012. o nadležnosti, priznavanju i izvršenju sudskih odluka u građanskim i trgovačkim stvarima (preinačena), ${ }^{14}$ (dalje: Uredba Brisel I bis), čl. 1. Uredbe Brisel II bis, čl. 1. Uredbe Vijeća (EZ) br. 4/2009 od 18. prosinca 2008. o nadležnosti, mjerodavnom pravu, priznavanju i izvršenju sudskih odluka te suradnji u stvarima koje se odnose na obvezu uzdržavanja ${ }^{15}$ (dalje: Uredba

11 Usporedi Preambulu (18) u vezi s odredbom čl. 3. st. 1. t. a Uredbe 2016/1103.

12 Ugovor o funkcioniranju Europske unije (pročišćeni tekst), Službeni list C 326, 26.10.2012., str. 47-390.

13 Naime, čl. 81. UFEU-a predviđa nadležnost EU-a za donošenje instrumenata kojim se uspostavlja pravosudna suradnja među državama članicama isključivo u sporovima $\mathrm{s}$ prekograničnim elementom. Slično Drličková, K.; Rohová, I., Habitual Residence as a Single Connecting Factor Under the Succession Regulation, u: Scientific Cooperations (ur.), Scientific Cooperations Workshops on Social Sciences, Ankara, Scientific Cooperations, 2015., str. 371381., na str. 374.

14 Uredba (EU) br. 1215/2012 Europskog parlamenta i Vijeća od 12. prosinca 2012. o nadležnosti, priznavanju i izvršenju sudskih odluka u građanskim i trgovačkim stvarima (preinačena), Službeni list EU, L 351, 20.12.2012., str. 1-32.

15 Uredba Vijeća (EZ) br. 4/2009 od 18. prosinca 2008. o nadležnosti, mjerodavnom pravu, 
4/2009 o uzdržavanju) i čl. 1. Uredbe 650/2012, u kojima također nije predviđeno da se postupci iz područja primjene pojedine uredbe imaju primjenjivati isključivo u postupcima s prekograničnim elementom. Istovremeno, europski instrumenti iz područja pravosudne suradnje kojima se propisuje mjerodavno pravo, poput Uredbe (EZ) br. 593/2008 Europskog parlamenta i Vijeća od 17. lipnja 2008. o pravu koje se primjenjuje na ugovorne obveze ${ }^{16}$ (dalje: Uredba Rim I), Uredbe (EZ) br. 593/2008 Europskog parlamenta i Vijeća od 17. lipnja 2008. o pravu koje se primjenjuje na ugovorne obveze (dalje: Uredba Rim I) ${ }^{17}$ i Uredbe (EZ) br. 864/2007 Europskog parlamenta i Vijeća 0d 17. srpnja 2007. o pravu koje se primjenjuje na izvanugovorne obveze (dalje: Uredba Rim III), ograničavajući područje svoje primjene na slučajeve koji uključuju sukob zakona, također ne predviđaju izrijekom da se njihova primjena odnosi na postupke s prekograničnim elementom. To je moguće izvesti iz okolnosti da pravila o sukobu zakona služe za rješavanje pitanja izbora mjerodavnog prava u sporovima u kojima postoji više paralelnih državnih sustava privatnog prava. ${ }^{18}$ Europski instrumenti koji uređuju unificirane europske građanske postupke definiraju prekogranični element postupaka u kojima se imaju primijeniti. ${ }^{19}$ Očigledno, podjednako svi ovdje razmotreni europski instrumenti iz područja pravosudne suradnje impliciraju ili izravno upućuju na primjenu u postupcima s prekograničnim elementom. No, ostaje otvoreno na koji se način ima odrediti odnosno prepoznati koji bi se od postupaka iz područja primjene pojedine uredbe trebali smatrati postupcima $\mathrm{s}$ prekograničnim elementom.

Iako se može učiniti da nije riječ o ozbiljnom nedostatku, primjena Uredbe 650/2012 u praksi u RH pokazala je da ova nepreciznost ostavlja prostora za dvojbe nadležnog tijela, kod nas konkretno, javnog bilježnika, koji postupa u određenom predmetu. ${ }^{20}$ Naime, činjenica je da će u nekim predmetima u kojima se odlučuje

priznavanju i izvršenju sudskih odluka te suradnji u stvarima koje se odnose na obvezu uzdržavanja, Službeni list EU, L 7, 10.1.2009., str. 1-79.

16 Uredba (EZ) br. 593/2008 Europskog parlamenta i Vijeća od 17. lipnja 2008. o pravu koje se primjenjuje na ugovorne obveze, Službeni list EU, L 177, 4.7.2008., str. 109-119.

17 Uredba (EZ) br. 864/2007 Europskog parlamenta i Vijeća od 17. srpnja 2007. o pravu koje se primjenjuje na izvanugovorne obveze, Službeni list EU, L 199/40, 31.07.2007.

18 Vuković, Đuro; Kunštek, Eduard, Međunarodno građansko postupovno pravo, Zgombić i partneri, 2005., str. 7-8.

19 Usporedi odredbu čl. 3. st. 1. Uredbe (EZ) br. 1896/2006 Europskog parlamenta i Vijeća od 12. prosinca 2006. o uvođenju postupka za europski platni nalog, Službeni list EU, L 399/1, 30.12.2006. (dalje: Uredba o europskom platnom nalogu) i odredbu čl. 3. st. 1. Uredbe (EZ) br. 861/2007 Europskog parlamenta i Vijeća od 11. srpnja 2007. o uvođenju europskog postupka za sporove male vrijednosti, Službeni list EU, L 199/1, 31.07.2007.

20 O problematici određenja kriterija kojima je moguće odrediti prekogranični element nasljednih stvari vidi Poretti, Paula, Nadležnost, nadležna tijela i postupci prema Uredbi (EU) br. 650/2012 o nasljeđivanju, Zbornik Pravnog fakulteta Sveučilišta u Rijeci, vol. 37., br. 1., 2016., str. 561-587. Istraživanje koje je autorica naknadno provela pokazalo je da, u malom broju predmeta u kojima su javni bilježnici do sada imali priliku postupati sukladno Uredbi 650/2012 o nasljeđivanju, u pravilu je prepoznato da je riječ o postupku s prekograničnim elementom. Nešto zahtjevnijim su se pokazali slučajevi u kojima je ostavitelj imao uobičajeno boravište u RH, kao i pretežni dio svoje imovine, i jedan otvoreni bankovni račun u drugoj državi članici, jer su u nekim od tih slučajeva javni bilježnici smatrali da bi trebali odlučiti isključivo o ostavini 
o bračnoimovinskom režimu biti razmjerno jednostavno odrediti da je riječ o prekograničnom elementu, no neće nužno uvijek biti tako. Primjerice, ako je riječ o postupku u kojemu se pretežni dio bračne stečevine bračnih drugova nalazi u jednoj državi članici, u kojoj bračni drugovi imaju uobičajeno boravište i čiji su državljani, a jedan ili više bankovnih računa u drugoj državi članici ili više njih, sudu može promaknuti da je riječ o postupku s prekograničnim elementom. ${ }^{21} \mathrm{U}$ pravnoj literaturi sugerirano je da bi bilo korisno detaljno propisati koji bi se postupci mogli smatrati postupcima s prekograničnim elementom ili ih barem primjerično navesti. O sličnoj ideji raspravljalo se i tijekom postupka izrade Uredbe 2016/1103, no kako se čini, rasprava nije rezultirala $u$ željenoj dopuni njezina teksta. ${ }^{22}$ Unatoč tomu što bi razlozi preglednosti i jednostavnije primjene u praksi govorili u prilog sugeriranoj dopuni teksta Uredbe 2016/1103, ako se uzme da određenje koji se postupci iz područja primjene određene uredbe imaju smatrati postupcima s prekograničnim elementom nije pronašlo svoje mjesto niti u jednoj od navedenih uredaba, osim onih koje reguliraju unificirane europske građanske postupke, nije bilo za očekivati da bi pristup europskog zakonodavca ovdje bio drukčiji. Stoga, ostaje poslužiti se određenjem iz Zelene knjige o sukobu zakona u stvarima koje se tiču bračnoimovinskih režima, ${ }^{23}$ koja svoje područje određuje "kao zajednice državljana različitih država članica ili njihova prisutnost u državi članici koja nije država njihova državljanstva, često popraćena stjecanjem imovine koja se nalazi na području više država članica". ${ }^{24}$

\section{NADLEŽNOST}

\subsection{Nadležnost sudova ako se postupak pokreće neovisno o razvodu ili ostavinskom postupku}

Imajući u vidu da se potreba raspravljanja i odlučivanja o bračnoimovinskom režimu bračnih drugova može pojaviti neovisno o pokretanju postupaka razvoda braka ili odlučivanja o ostavini, Uredba 2016/1103 predviđa niz hijerarhijski strukturiranih pravila kojima se određuje nadležnost suda države članice da u tim slučajevima postupa u određenom predmetu. Kao temeljni kriterij za određivanje nadležnosti u tim slučajevima odredba čl. 6. Uredbe 2016/1103 predviđa kriterij uobičajenog boravišta bračnih drugova, i to tako da se najprije uzima u obzir uobičajeno boravište bračnih drugova u trenutku pokretanja postupka pred sudom (arg. ex čl. 6. t. a), zatim posljednjeg zajedničkog uobičajenog boravišta bračnih drugova, ako jedan od njih

koja se nalazi u RH te upućivali stranke da za novčana sredstva na bankovnom računu provedu postupak u državi članici u kojoj se račun nalazi.

21 Slično, Grey, Jacqueline; Redondo, Pablo Quinzá, Stress-testing the EU Proposal on Matrimonial Property Regimes: Co-operation between EU private international law instruments on family law and successions, str. 4., dostupno na: http://www.familyandlaw.eu/tijdschrift/fenr/2013/11/ FENR-D-13-00008, 1.02.2017.

22 Loc. cit.

23 Zelena knjiga o sukobu zakona u stvarima koje se tiču bračnoimovinskih režima, uključujući pitanja nadležnosti i priznanja, $\operatorname{COM}(2006) 400$ fin.

24 Grey, J.; Redondo, P. Q., op. cit., str. 5. 
još uvijek tamo boravi u trenutku pokretanja postupka pred sudom (arg.ex čl. 6. t. b) ili na čijem državnom području protustranka ima uobičajeno boravište u trenutku pokretanja postupka pred sudom (arg. ex čl. 6. t. c) ili ako nije moguće utvrditi nadležnosti na temelju niti jednog od ponuđenih kriterija uobičajenog boravišta, nadležnost se ima podredno utvrditi prema zajedničkom državljanstvu bračnih drugova u trenutku pokretanja postupka pred sudom (arg. ex čl. 6. t. d). Odabirom uobičajenog boravišta kao temeljnog kriterija, a državljanstva kao podrednog, za utvrđivanje nadležnosti suda države članice, Uredba 2016/1103 još jednom podcrtava ideju koja je prisutna u pretežnom broju instrumenata iz toga područja, počevši od Haške konvencije o mjerodavnom pravu za bračnoimovinske režime iz 1978. (dalje: Haška konvencija iz 1978. . $^{25}$, pa sve do Uredbe Brisel II bis te Uredbe 650/2012, da se primjenom, osobito, kriterija uobičajenog boravišta, ide za tim da se uvaži sve prisutnija mobilnost građana kojima se nastoji osigurati jedinstveni standard pravne zaštite, neovisno u kojoj se državi članici nalaze. I ovdje je izostalo određenje pojma uobičajenog boravišta, podjednako kao i u ranije spomenutim instrumentima, u odnosu na što su upućene određene kritike ${ }^{26}$, pa je pravna teorija upozorila na potrebu autonomne interpretacije Uredbe 2016/1103. ${ }^{27} \mathrm{U}$ tom smislu, kriterij uobičajenog boravišta i ovdje ima značaj faktične veze između bračnih drugova i države članice čiji je sud nadležan (arg. ex Preambula (35)). No, za razliku od Uredbe 650/2012 o nasljeđivanju koja u Preambulu (24) i (25) donosi pomoćna, interpretativna pravila za utvrđivanje uobičajenog boravišta u situacijama u kojima ga nadležno tijelo ne bi moglo bez teškoća odrediti, Uredba 2016/1103 ne slijedi njezin primjer. Razloge za to moguće je vidjeti u okolnosti da se režim Uredbe 2016/1103 u pretežnom dijelu ima primjenjivati za postupanja u pogledu bračnoimovinskog režima u okviru postupaka razvoda braka ili odlučivanja o nasljeđivanju, pa će se uobičajeno boravište u tim slučajevima utvrđivati uz pomoć tumačenja koja je u svojim judikatima dao Europski sud, vezano uz primjenu Uredbe 2201/2003 te interpretativnih pravila iz Preambule Uredbe 650/2012 o nasljeđivanju. ${ }^{28}$

Ako su se stranke sporazumjele da mjerodavno pravo bude pravo države u kojoj bračni ili budući bračni drugovi ili jedan od njih ima uobičajeno boravište u trenutku kad je sporazum sklopljen (arg. ex 22. st. 1. t. a), pravo države državljanstva jednog od bračnih drugova ili budućih bračnih drugova u trenutku kad je sporazum sklopljen (arg. ex čl. 22. st. 1. t. b) ili ako sporazum nije sklopljen, pa je prema pravilima Uredbe 2016/1103 mjerodavno pravo prvog zajedničkog uobičajenog boravišta bračnih

25 Konvencija od 14. ožujka 1978. o mjerodavnom pravu za bračnoimovinski režim, stupila na snagu 1. rujna 1992. Dostupno na: http://www.hcch.net/index_en.php?act=conventions. status\&cid=87. A. E. von Overbeck, Explanatory Report on the 1978 Hague Matrimonial Property Regimes Convention, The Hague, 1978.

26 Usporedi Poretti, P., op. cit., str. 566-571.

27 Pintens, Walter, Applicable law in the Proposal for Regulation on matrimonial property law, u: Successions and matrimonial property regimes in Europe: notarial solutions, Société de législation comparée, Paris, 2014., str. 88.

28 Više o pojmu uobičajnog boravišta u judikatima Europskog suda vidi Poretti, P., op. cit., str. 566-567. Također, važni su i predmeti C-443/03 - Leffler, ECLI:EU:C:2005:665 i C-497/10 PPU - Mercredi, ECLI:EU:C:2010:829. 
drugova nakon sklapanja braka (arg. ex čl. 26. st. 1. t. a) ili zajedničkog državljanstva bračnih drugova u trenutku sklapanja ugovora (arg. ex čl. 26. st. 1. t. b), Uredba 2016/1103 omogućuje bračnim drugovima da se sporazumiju da sud države članice čije je pravo mjerodavno prema nekoj od odredaba ili sud države članice u kojoj je brak sklopljen (arg. ex čl. 7. st. 1.) bude isključivo nadležan odlučivati u stvarima njihova bračnoimovinskog režima (arg. ex čl. 7. st. 1.). Nadalje, u čl. 8. Uredba 2016/1103 predviđa da je sud države članice čije je pravo mjerodavno sukladno odredbama čl. 22. ili čl. 26. st. 1. t. a i b nadležan i ako se tuženik pred njim upusti u postupak, osim ako se tuženik upustio u postupak radi osporavanja nadležnosti ili ako je s obzirom na koncentraciju nadležnosti za postupanje nadležan sud države članice za donošenje odluke o nasljeđivanju (arg. ex čl. 4.) ili razvod braka, zakonsku rastavu ili poništaj braka (arg. ex čl. 5. st. 1.). Pravila čl. 7. (o izboru prava) i 8. (o nadležnosti suda pred kojim se tuženik upustio u postupak) naglašavaju autonomiju volje stranaka, u prvom redu u dijelu u kojemu omogućuju bračnim drugovima sporazumijevanje o nadležnosti suda, odnosno tuženiku izbor nadležnog suda upuštanjem u postupak, ali i u dijelu u kojemu su među sudovima koje bračni drugovi mogu izabrati kao nadležne, sudovi država članica čije je pravo izabrano kao mjerodavno sukladno odredbi čl. 22. Uredbe 2016/1103. Uređivanje pravila o izboru suda utemeljeno je na shvaćanju kojega naglašava Preambula (36) Uredbe 2016/1103, da se time povećava pravna sigurnost, predvidljivost i autonomija stranaka. Očigledno, i ovdje kao i kod Uredbe 650/2012 o nasljeđivanju ide se za tim da se osigura da sud koji je nadležan primjenjuje vlastito pravo.

\subsection{Nadležnost u slučaju smrti bračnih drugova}

Premda Uredba 2016/1103 predviđa primjenu pravila o nadležnosti i mjerodavnom pravu i za slučajeve kada se u stvarima bračnoimovinskog režima odlučuje u zasebnim postupcima, njome se ponajprije, pravilima o koncentraciji nadležnosti, nastojalo osigurati da, u različitim povezanim postupcima, sudovi države članice koji odlučuju o nasljeđivanju ili u postupka razvoda braka, ujedno odlučuju i u stvarima bračnoimovinskog režima (arg. ex Preambula (32)).

Stoga, Uredba 2016/1103 u čl. 4. predviđa da će ako je pred sudom države članice pokrenut postupak u stvarima nasljeđivanja bračnog druga u skladu s Uredbom 650/2012 o nasljeđivanju, sud te države članice biti nadležan za odlučivanje o stvarima bračnoimovinskog režima povezanima s tim predmetom nasljeđivanja. Imajući $u$ vidu osobitosti uređenja u hrvatskom pravnom sustavu gdje, osim općinskog suda, javni bilježnik kao povjerenik suda provodi ostavinski postupak, potrebno je najprije izvršiti analizu usklađenosti režima Uredbe 2016/1103 u dijelu u kojemu određuje pojam "sud” s nacionalnim pravilima o postupanju nadležnih tijela za donošenje odluke o nasljeđivanju, koja će ujedno biti nadležna i za odlučivanje u stvarima bračnoimovinskog režima. Zbog kratkog razdoblja od donošenja Uredbe 2016/1103, u hrvatskom pravnom sustavu još nisu razrađene provedbene odredbe koje bi olakšale njezinu primjenu ${ }^{29}$ te je stoga potrebno osloniti se na interpretativna pravila iz njezine

29 Za sada nije poznato hoće li se hrvatski zakonodavac opredijeliti za izradu zasebnog propisa, 
Preambule, odnosno dovesti ih u vezu s odredbama Uredbe 650/2012 i odredbama Zakona o provedbi Uredbe 650/2012o nasljeđivanju. ${ }^{30}$ Iz Preambule (29) Uredbe 2016/1103 proizlazi da pojam "sud” osim sudova koji izvršavaju sudske funkcije, obuhvaća i javne bilježnike koji u stvarima bračnoimovinskog režima izvršavaju sudske funkcije poput sudova ili te funkcije izvršavaju na temelju ovlasti koje im je prenio sud. Na javne bilježnike koji izvršavaju sudsku funkciju primjenjuju se pravila o nadležnosti iz Uredbe 2016/1103 kao i pravila o priznavanju i izvršavanju odluka koje donose u stvarima bračnoimovinskog režima (arg. ex Preambula (31)). Budući da je u hrvatskom pravnom sustavu javni bilježnik, kao povjerenik suda, tijelo nadležno za postupanje u ostavinskom postupku, postupanje javnog bilježnika u predmetima s prekograničnim elementom proizlazi iz odredbe čl. 11. st. 3. Zakona o provedbi Uredbe 650/2012 o nasljeđivanju koja izravno upućuje na primjenu odredaba ZNa. ${ }^{31,32}$

Iz toga se dade zaključiti da će ako je hrvatski sud odnosno javni bilježnik nadležan za odlučivanje o nasljeđivanju sukladno Uredbi 650/2012, podjednako hrvatski sud odnosno javni bilježnik moći odlučivati i u stvarima bračnoimovinskog režima sukladno Uredbi 2016/1103. Tako bi u prekograničnom predmetu nasljeđivanja javni bilježnik kao povjerenik suda sukladno Uredbi 650/2012 o nasljeđivanju, bio nadležan odlučiti u stvarima bračnoimovinskog režima sukladno Uredbi 2016/1103, no samo ako su one nesporne među nasljednicima. U tom bi slučaju rješenjem o nasljeđivanju javni bilježnik rasporedio imovinu umrlog bračnog druga na nasljednike, uz navođenje dijela imovine koji kao bračna stečevina pripada preživjelom bračnom drugu. Budući da se prema Preambuli (27) i (28) Uredbe 2016/1103 evidentiranje u upisnik prava na nepokretnoj imovini provodi prema pravu države članice u kojoj se vodi upisnik, a to je za nepokretnu imovinu pravo države u kojoj se nalazi nekretnina, za upis prava preživjelog bračnog druga na nekretnini u RH primjenjivalo bi se nacionalno pravo. No, iz sudske prakse proizlazi da takvo rješenje o nasljeđivanju, u dijelu u kojemu navodi imovinu koja je bračna stečevina preživjelog bračnog druga, neće biti dostatna osnova za uknjižbu prava vlasništva preživjelog bračnog druga u zemljišnu knjigu u RH te će naknadno biti potrebno pokrenuti postupak iz kojega će bračni drug steći valjanu osnovu za uknjižbu te imovine. Ako se okolnost da rješenje pitanja podjele bračne stečevine u ostavinskom postupku kojega provodi javni bilježnik ima učinak ograničen na tu parnicu, osobito u dijelu odluke koji se odnosi na nekretnine, razmatra u svjetlu intencije da se donošenjem Uredbe 2016/1103 omogući da nadležno tijelo pri donošenju odluke o ostavini u predmetima s prekograničnim elementom odluči i o bračnoimovinskom režimu te da se preživjelom bračnom drugu omogući uživanje u stečenim pravima u državi članici, očigledno je da trenutno način postupanja u

u vidu provedbenog zakona ili će provedbene odredbe uz Uredbu 2016/1103 integrirati u postojeći pravni propis.

30 Zakon o provedbi Uredbe (EU) br. 650/2012 Europskog parlamenta i Vijeća od 4. srpnja 2012. o nadležnosti, mjerodavnom pravu, priznavanju i izvršavanju odluka i prihvaćanju i izvršavanju javnih isprava u nasljednim stvarima i o uspostavi Europske potvrde o nasljeđivanju, NN, br. $152 / 14$.

31 Zakon o nasljeđivanju, NN, br. 48/03., 163/03., 35/05., 127/13., 33/15.

32 Usporedi Poretti, P., op. cit., str. 574. 
hrvatskom pravnom sustavu nije odgovarajući. Bilo bi potrebno osigurati da se na temelju odluke donesene u okviru ostavinskog postupka, a koja se tiče podjele bračne stečevine može upisati pravo na nekretnini preživjelog bračnog druga, bez potrebe za vođenjem naknadnog postupka kako bi se pribavila odluka na temelju koje bi se izvršio upis.

Ako je pitanje podjele bračne stečevine sporno u ostavinskom postupku, javni bilježnik o njemu neće odlučivati nego će stranke uputiti da pokrenu postupak pred sudom. I u tom bi slučaju sud nadležnost za odlučivanje o bračnoimovinskom režimu utemeljio na odredbi čl. 4. Uredbe 2016/1103. Time je postupanje u predmetima nasljeđivanja s prekograničnim elementom, u kojima je potrebno odlučiti o pitanju podjele bračne stečevine pojednostavljeno, jer će o njemu biti nadležan odlučiti sud u parnici koja se vodi u pogledu ostavine, što pravila sukoba zakona nisu uvijek osiguravala. Naime, prema pravilima sukoba zakona bilo je moguće da sud jedne države odlučuje o stvarima bračnoimovinskog režima, a da se potom pred sudom druge države vodi ostavinski postupak.

No, treba imati u vidu da je režim Uredbe 650/2012 o nasljeđivanju nastajao neovisno o režimu Uredbe 2016/1103, zbog čega nije moguće govoriti o potpunoj usklađenosti njihovih pravila. Ta se primjedba u najvećoj mjeri odnosi na primjenu odredbe čl. 5. Uredbe 650/2012 o nasljeđivanju prema kojoj, ako je ostavitelj za uređenje svog nasljeđivanja odabrao kao mjerodavno pravo države članice čiji je bio državljanin u trenutku odabira ili u trenutku smrti, stranke na koje se to odnosi ${ }^{33}$ mogu se sporazumjeti da sud ili sudovi te države članice imaju isključivu nadležnost odlučivati o tom pitanju. Iz toga proizlazi da bi se u ostavinskom postupku kojemu se ima riješiti pitanje bračnoimovinskog režima, svi sudionici, uključujući preživjela bračnog druga, trebali sporazumjeti o prihvaćanju nadležnosti suda države članice državljanstva ostavitelja, umjesto nadležnosti suda države članice uobičajenog boravišta ostavitelja u trenutku smrti. Pritom ostaje otvoreno bi li se u odnosu na nadležnost za rješavanje o pitanju bračnoimovinskog režima strankama na koje se odnosi sporazum o nadležnosti imali smatrati svi sudionici u postupku ili samo preživjeli bračni drug, jer se odluka o stvarima bračnoimovinskog režima tiče njegovih prava i interesa, a tek je od posrednog učinka na prava i interese ostalih sudionika, budući da utječe na podjelu imovine umrlog odnosno udio koji će se kao ostavina rasporediti među nasljednicima. Ako se uzme da bi sporazum o nadležnosti suda države članice državljanstva ostavitelja trebali postići svi sudionici u postupku, potrebno je razmotriti okolnosti u kojima se takav sporazum ima postići. Moguće je zamisliti situacije u kojima je ostavitelj za života, u dogovoru sa svojim bračnim drugom izabrao kao pravo mjerodavno za odlučivanje o ostavini pravo države članice čiji je državljanin, imajući u vidu da će sudovi te države članice odlučivati o njegovoj ostavini i o bračnoimovinskom režimu bračnih drugova. Za pretpostaviti je da će bračni drug koji je upućen u izbor prava državljanstva umrlog bračnog druga kao mjerodavnog, biti suglasan s prijenosom nadležnosti na sud te države članice. Istovremeno, moguće je da se ostali sudionici odnosno nasljednici (stranke prema dikciji čl. 5. Uredbe 650/2012) ne suglase s prijenosom te da kao nadležan u predmetu

33 U tekstu istaknula autorica. 
postupa sud države članice uobičajenog boravišta umrlog u trenutku smrti. Zamisliv je i obrnut slučaj, u kojemu će sudionici odnosno nasljednici imati interesa da nadležan bude sud države članice državljanstva umrlog te da se primjenjuje pravo te države članice. Razlozi razilaženja o sporazumu o izboru suda mogu biti različiti, no zasigurno se mogu pronaći i u intenciji sudionika u postupku da osiguraju postupanje suda države članice njihova uobičajenog boravišta ili suda pred kojim će se kao mjerodavno primijeniti pravo one države članice koje im u većoj mjeri pogoduje. U slučaju nemogućnosti postizanja sporazuma među sudionicima, bilo koji od sudionika može prema odredbi čl. 6. st. 1. Uredbe 650/2012 o nasljeđivanju zatražiti od suda odbiti nadležnost za postupanje, ako ocijeni da bi sud države članice državljanstva umrlog bio u boljem položaju za rješavanje o nasljeđivanju. No, time se sudioniku koji je nezadovoljan izostankom sporazuma o nadležnosti ne jamči da će uvijek doći do odbijanja nadležnosti suda uobičajenog boravišta i da će nadležan biti sud države članice državljanstva umrlog, budući da se procjena o odbijanju nadležnosti suda temelji na praktičnim okolnostima slučaja, primjerice, mjestu gdje se nalazi imovina (arg. ex čl. 6. st. 1. t. a Uredbe 650/2012 o nasljeđivanju).

Pravna teorija s pravom je zamjerila ovom rješenju da ne vodi dovoljno računa o interesu preživjela bračnog druga, u odnosu na odabir suda države članice za rješavanje bračnoimovinskog režima u okviru ostavinskog postupka. Stoga je u odnosu na čl. 3. Prijedloga Uredbe 2016/1103 (sada čl. 4. Uredbe 2016/1103) sugerirala da bi bilo oportuno predvidjeti da bi preživjeli bračni drug trebao izrijekom pristati da sud države članice pred kojim je pokrenut postupak u stvarima nasljeđivanja bude nadležan za odlučivanje u stvarima bračnoimovinskog režima povezanima s tim predmetom nasljeđivanja. ${ }^{34}$

Problem se javlja i kod primjene odredbe čl. 10. Uredbe 650/2012 o nasljeđivanju kojom se ako je uobičajeno boravište ostavitelja bilo u trećoj državi, kao supsidijarna uspostavlja nadležnost suda države članice u kojoj se nalazi imovina, ako je ostavitelj bio državljanin te države članice (arg. exčl. 10. st. 1. a) ili je imao svoje prethodno uobičajeno boravište u toj državi članici, a u trenutku pokretanja postupka nije prošlo više od pet godina od promjene tog uobičajenog boravišta (arg. ex čl. 10. st. 1. b). Ako niti jedan sud države članice ne bi imao nadležnost sukladno st. 1., sud države članice gdje se nalazi imovina bio bi nadležan odlučivati o toj imovini. U odnosu na slučajeve iz odredbe čl. 10 st. 1 . Uredbe 650/2012 o nasljeđivanju, ako su bračni drugovi u trenutku smrti ostavitelja imali uobičajeno boravište u trećoj državi, nadležnost suda države članice državljanstva ili uobičajenog boravišta ostavitelja za odlučivanje o bračnoimovinskom režimu neće nužno odgovarati interesima preživjela bračnog druga, no s obzirom na odredbu čl. 4. Uredbe 2016/1103, neće je moći otkloniti. Još će veće poteškoće i nejasnoće izazvati primjena odredbe čl. 10. st. 2. Uredbe 650/2012 o nasljeđivanju, prema kojoj bi za odlučivanje o bračnoimovinskom režimu bračnih drugova, ako je ostavitelj u trenutku smrti imao uobičajeno boravište u trećoj državi, nadležan bio sud države članice u kojoj je nalazi imovina, ali samo za taj dio imovine. Ovisno o tomu jesu li bračni drugovi imali zajedničku imovinu u jednoj ili više država članica, nadležan će biti jedan ili više sudova za odlučivanje u

34 Grey, J.; Redondo, P. Q., op. cit., str. 11. 
stvarima bračnoimovinskog režima, i to, za pretpostaviti je, svaki od sudova države članice za imovinu koja se nalazi na području te države članice. Time je ugrožena ideja o nadležnosti samo jednoga suda države članice za rješavanje o nasljeđivanju i u stvarima bračnoimovinskog režima.

\section{MJERODAVNO PRAVO}

Uredba 2016/1103 predviđa dva načina na koja je moguće utvrditi koje je pravo mjerodavno za odlučivanje o bračnoimovinskom režimu, na temelju izbora mjerodavnog prava koji su izvršili bračni drugovi (arg. ex čl. 22.) ili na temelju pravila o mjerodavnom pravu kada nije izvršen izbor (arg. ex čl. 26.).

Za razliku od Uredbe 650/2012 o nasljeđivanju koja vodi računa o tomu da u nekim slučajevima osoba može imati više državljanstava te ostavlja mogućnost odabira kao mjerodavnog pravo bilo koje od država članica čiji je osoba državljanin (arg. ex čl. 22. st. 1.), Uredba 2016/1103 u pogledu izbora prava utemeljenog na državljanstvu ograničava se isključivo na pravo države čiji je jedan od bračnih drugova odnosno budućih bračnih drugova državljanin u trenutku kada je sklopljen sporazum (arg. ex čl. 22. st. 1. t. b). To je rješenje kritizirala pravna teorija, koja je upozorila da je ono, budući da se oslanja isključivo na državljanstvo države članice u kojoj je sporazum sklopljen, i daje mu prednost pred drugim kriterijima koji se temelje na državljanstvu, protivno judikaturi Europskog suda. ${ }^{35,36}$ No, kritizirano rješenje istovremeno moguće je promatrati u svjetlu nekoliko temeljnih ideja razvijenih u okviru režima Uredbe 2016/1103.

Budući da Uredba 2016/1103 u odredbi čl. 23. govori o formalnoj valjanosti sporazuma kada je kao mjerodavno izabrano pravo uobičajenog boravišta bračnih drugova ili jednog od njih, argumentum per analogium dade se zaključiti da bi razlozi praktičnosti govorili u prilog rješenju da se izbor prava ograniči na pravo države članice čije državljanstvo ima jedan od bračnih drugova odnosno budućih bračnih drugova u trenutku sklapanja sporazuma, jer bi se tako osiguralo da se formalnosti, uključujući i valjanost sporazuma procjenjuje prema pravu države u kojoj je sporazum sklopljen. Istovremeno, autonomija volje bračnih drugova koja se odnosi na mogućnost izbora prava s kojim su blisko povezani kao mjerodavnog prava, neovisno o vrsti imovine i mjestu gdje se nalazi (arg. ex Preambula (45), pri čemu je državljanstvo jedna od tih poveznica, otklanja prigovor da bi u slučajevima u kojima osoba ima više državljanstava, isključivo državljanstvo one države pred kojom se sporazum sklapa imalo prednost. Naime, bračni drugovi slobodni su sklopiti sporazum u bilo kojoj državi članici čije državljanstvo ima bračni drug koji ima više državljanstava, dajući tako prednost državljanstvu one države članice čije su pravo odabrali kao mjerodavno.

35 Predmeti C-148/02 - Garcia Avello, ECLI:EU:C:2003:539; C-168/08 - Hadadi, ECLI:EU:C:2009:474.

36 Vidi Pintens, W., op. cit., str. 87.; Martiny, Dieter, Die Kommissionsvorschläge für das internationale Ehegüterrecht sowie für das internationale Güterrecht eingetragener Partnerschaften, , IPRax, vol. 31., br. 5., 2011., str. 449. 


\subsection{Primjena materijalnog prava u slučaju smrti bračnoga druga}

U nastavku će biti detaljnije analizirana pravila o primjeni mjerodavnog prava prema Uredbi 2016/1103 koja bi, osobito u slučajevima gdje nije učinjen izbor prava, trebala biti usklađena s pravilima o primjeni mjerodavnog prava prema Uredbi 650/2012 o nasljeđivanju, kako bi se osigurala primjena jedinstvenog prava za rješavanje predmeta, i to, kad god je moguće, prava države članice čiji je sud nadležan za postupanje u stvarima nasljeđivanja.

U slučajevima u kojima se bračni drugovi sporazumiju o bračnoimovinskom režimu, mjerodavno je pravo države u kojoj bračni ili budući bračni drugovi ili jedan od njih ima uobičajeno boravište u trenutku kad je sporazum sklopljen (arg. ex 22. st. 1. a) ili pravo države državljanstva jednog od bračnih drugova ili budućih bračnih drugova u trenutku kad je sporazum sklopljen (arg. ex čl. 22. st. 1. b). Promjena mjerodavnog prava učinjena tijekom braka ima učinak pro futuro, ako se bračni drugovi drukčije ne sporazumiju (arg. ex čl. 22. st. 2.).

Ako se uzme da se u ostavinskim postupcima prema općem pravilu kao mjerodavno primjenjuje pravo uobičajenog boravišta ostavitelja u trenutku smrti (arg. ex čl. 21. st. 1. Uredbe 650/2012 o nasljeđivanju), u velikom broju slučajeva gdje su bračni drugovi izabrali kao mjerodavno za odlučivanje o bračnoimovinskom režimu pravo svojega uobičajenog boravišta u trenutku sklapanja sporazuma, koje je tijekom zajedničkog života bračnih drugova ostalo nepromijenjeno, sud države članice uobičajenog boravišta ostavitelja u trenutku smrti će u ostavinskom postupku primjenjivati vlastito pravo za odlučivanje o ostavini i u stvarima bračnoimovinskog režima (arg. ex čl. 4. Uredbe 650/2012 u vezi s čl. 21. t. 1. t. a Uredbe 2016/1103). No, ako je za života bračnih drugova došlo do promjene uobičajenog boravišta ostavitelja ili oba bračna druga, te ostavitelj u toj državi članici umre, izabrano mjerodavno pravo za odlučivanje o bračnoimovinskom režimu više neće biti podudarno s pravom mjerodavnim za odlučivanje o ostavini. U tom smislu, čini se da se neće moći bez poteškoća osigurati primjena istoga mjerodavnog prava za odlučivanje o ostavini i bračnoimovinskom režimu, i k tome, prava države članice suda koji je nadležan za postupanje. Ako bi bračni drugovi kao mjerodavno izabrali pravo države državljanstva jednog od bračnih drugova ili budućih bračnih drugova u trenutku kad je sporazum sklopljen u skladu s odredbom čl. 22. st. 1. t. b Uredbe 2016/1103, a bračni drug bi kao ostavitelj za pravo koje će urediti u cijelosti njegovo nasljeđivanje izabrao pravo države čiji je državljanin u trenutku izbora ili u trenutku smrti sukladno odredbi čl. 22. st. 1. Uredbe 650/2012 o nasljeđivanju, ako je riječ o pravu iste države članice, ono bi bilo mjerodavno za odlučivanje, neovisno o tomu bi li za života bračnih drugova došlo do promjene njihova uobičajenog boravišta.

Ako bračni drugovi nisu izvršili izbor mjerodavnog prava, mjerodavno može biti pravo prvog zajedničkog uobičajenog boravišta bračnih drugova nakon sklapanja braka (arg. ex čl. 26. st. t. a). Za razliku od Uredbe 650/2012 koja se oslanja na uobičajeno boravište umrlog u trenutku smrti kao konačan, nepromjenjiv kriterij, njegova primjena u odnosu na bračnoimovinski režim problematična je, ako se pretpostavi da će bračni drugovi za života mijenjati svoje uobičajeno boravište 
odnosno seliti se u druge države članice. Stoga je prikladnija primjena kriterija prvoga zajedničkog uobičajenog boravišta koji nije podložan promjenama, odnosno buduće okolnosti bračnih drugova ne utječu na mjerodavno pravo koje će se primjenjivati na rješavanje pitanja bračnoimovinskog režima bračnih drugova. Uredba 2016/1103 podredno predviđa primjenu kriterija zajedničkog državljanstva bračnih drugova u trenutku sklapanja sporazuma (arg. ex čl. 26. st. 1. t. b) ili prava s kojim su bračni drugovi zajedno najbliže povezani, uzimajući u obzir sve okolnosti (arg. ex čl. 26. st. 1. t. c). Čini se da se pri odabiru kriterija za utvrđivanje prava mjerodavnog za odlučivanje vodilo računa da se osigura bliska veza između bračnih drugova i države članice čije će se pravo primjenjivati. Hijerarhija između predviđenih kriterija vodi računa o stvarnim životnim okolnostima bračnih drugova. ${ }^{37} \mathrm{U}$ tom smislu, prednost $\mathrm{i}$ ovdje ima kriterij uobičajenog boravišta koji pretpostavlja određenu razinu integracije u sredinu u kojoj bračni drugovi žive u trenutku sklapanja sporazuma, ali istovremeno je u dostatnoj mjeri fleksibilan jer se temelji na uspostavljanju faktične veze između bračnih drugova i države članice. U slučajevima gdje nije moguće primijeniti kriterij prvog zajedničkog uobičajenog boravišta, jer primjerice od sklapanja braka bračni drugovi žive i rade u različitim državama članicama, ili iz okolnosti slučaja proizlazi da nisu uspostavili dostatnu vezu s državom članicom uobičajenog boravišta, ponuđen je kriterij zajedničkog državljanstva bračnih drugova u trenutku sklapanja braka. Premda je u usporedbi s kriterijem uobičajenog boravišta riječ o stabilnijem kriteriju, kojega je jednostavnije odrediti, kritika koja mu se može uputiti tiče se ograničenosti njegove primjene na situacije u kojima oba bračna druga imaju državljanstvo iste države članice. Posljednji kriterij, prema kojemu se ima primijeniti pravo države članice s kojom su bračni drugovi zajednički najbliže povezani, primjenjivao bi se tek ako za primjenu prethodna dva ne bi postojali uvjeti, pa se i njegova neodređenost može razumjeti tako da se željelo osigurati da odgovara primjeni u velikom broju slučajeva za koje nije moguće osigurati primjenu ostalih poveznica. Postupanje pri odlučivanju o bračnoimovinskom režimu trebala bi olakšati i iznimka u vidu mogućnosti da se na zahtjev jednog od bračnih drugova umjesto mjerodavnog prava države članice prvoga zajedničkog uobičajenog boravišta bračnih drugova primijeni pravo države članice u kojoj su bračni drugovi imali posljednje zajedničko uobičajeno boravište znatno dulje nego u državi članici prvog zajedničkog uobičajenog boravišta te da su se u uređivanju i planiranju svojih odnosa oba bračna druga oslanjala na pravo te druge države članice (arg. ex čl. 26. st. 3. t. a i b). Pritom nije potpuno jasno zbog čega se u odredbi čl. 26. st. 3. Uredbe 2016/1103 umjesto pojma sud koristi pojam pravosudno tijelo, jer ništa u odredbi ne upućuje na to da bi se ova odredba, u odnosu na tijela nadležna za postupanje, imala tumačiti različito od ostalih odredaba.

Analiza primjene odredaba o mjerodavnom pravu za odlučivanje o stvarima bračnoimovinskog režima ukazuje na određenu neujednačenost u odnosu na pravila o mjerodavnom pravu sukladno Uredbi 650/2012 o nasljeđivanju.

Ako se uzme da bi u ostavinskom postupku sukladno odredbi čl. 21. Uredbe 650/2012 bilo mjerodavno pravo uobičajenog boravišta ostavitelja u trenutku smrti, samo u onim slučajevima gdje bračni drugovi nisu mijenjali svoje uobičajeno boravište,

37 Tako Preambula (21) Prijedloga Uredbe 2016/1103. 
primjena odredbe čl. 26. st. 1. t. a Uredbe 2016/1103 o mjerodavnom pravu prvoga zajedničkog uobičajenog boravišta bračnih drugova omogućavala bi da isto pravo bude mjerodavno za donošenje odluke o nasljeđivanju i o bračnoimovinskom režimu, koje je ujedno i pravo države članice čiji je sud nadležan za odlučivanje u ostavinskom postupku. Ako se uobičajeno boravište promijenilo, odnosno ako su se bračni drugovi za života preselili u drugu državu članice, za odlučivanje o bračnoimovinskom režimu bilo bi mjerodavno pravo države članice njihova prvog zajedničkog uobičajenog boravišta, dok bi za odlučivanje o nasljeđivanju bilo mjerodavno pravo uobičajenog boravišta umrlog bračnog druga u trenutku smrti, odnosno pravo države članice u koju su se preselili bračni drugovi.

Mogućnost koordinacije kriterija za određivanje prava mjerodavnog za nasljeđivanje prema odredbi čl. 21. Uredbe 650/2012 o nasljeđivanju i odlučivanje o bračnoimovinskom režimu na zahtjev jednog od bračnih drugova pruža i iznimka predviđena odredbom čl. 26. st. 3. Uredbe 2016/1103, uz uvjet da podnositelj zahtjeva dokaže da su ispunjene pretpostavke o dužem razdoblju boravka u drugoj državi članici i primjeni prava te države članice u uređenju imovinskih odnosa bračnih drugova. Isto tako, ako bi ostavitelj kao mjerodavno za odlučivanje u ostavinskom postupku izabrao pravo države članice čiji je državljanin u trenutku izbora ili u trenutku smrti sukladno odredbi čl. 22. st. 1. Uredbe 650/2012, odabir prava državljanstva jednog od bračnih drugova, ako je on ujedno ostavitelj, u trenutku kad je sporazum sklopljen, kao mjerodavnog za odlučivanje u stvarima bračnoimovinskog režima u skladu s odredbom čl. 22. st. 1. t. b Uredbe 2016/1103 osiguravao bi primjenu prava iste države članice kao mjerodavnog za odlučivanje o svim stvarima u postupku. Naime, iako se trenutak u odnosu na koji se veže kriterij državljanstva ovdje razlikuje, pa je tako za nasljeđivanje važan trenutak izbora mjerodavnog prava ili trenutak smrti, a za bračnoimovinski režim trenutak postizanja sporazuma o mjerodavnom pravu, za pretpostaviti je da se trajna i stabilna spona osobe s državom članicom, koju pretpostavlja državljanstvo pojedine države članice neće raskidati odnosno da se državljanstvo bračnog druga neće mijenjati. Međutim, premda je iz perspektive režima Uredbe 2016/1103 ova koordinacija prava mjerodavnog za odlučivanje o nasljeđivanju i u stvarima bračnoimovinskog režima poželjna, ne treba zanemariti da se njome ipak u većoj mjeri pogoduje interesima jednog od bračnih drugova, onoga koji je državljanin države članice čije će se pravo primijeniti kao mjerodavno. Naime, pravna teorija zamjera da će se na taj način na prava i interese preživjelog bračnog druga kao mjerodavno primjenjivati pravo s kojim nije povezan i potencijalno ga niti ne poznaje..$^{38} \mathrm{No}$, čini se da pritom gubi iz vida da se preživjeli bračni drug prethodno suglasio s primjenom prava države članice čiji je drugi bračni drug odnosno ostavitelj bio državljanin kao mjerodavnog za odlučivanje u stvarima bračnoimovinskog režima. Iz toga razloga, kao primjerenije rješenje predlaže izmjenu Uredbe 650/2012 o nasljeđivanju koja bi omogućila da se kao mjerodavno u ostavinskom postupku primjenjuje pravo mjerodavno za odlučivanje o bračnoimovinskom režimu. ${ }^{39}$

38 Grey, J.; Redondo, P. Q., op. cit., str. 24.

39 Loc. cit. 


\section{ZAKLJUČAK}

Ideja o europskom instrumentu kojim će se ukloniti prepreke slobodnom kretanju osoba i poteškoća s kojima se suočavaju bračni drugovi pri upravljanju svojom imovinom ili pri njezinoj podjeli dugi niz godina dijelom je teorijskih rasprava ${ }^{40}$ te predmetom opsežnih istraživanja i konačno, intenzivnog legislativnog djelovanja EUa. ${ }^{41}$ Premda njezino oživotvorenje u Uredbi 2016/1103 nije rezultiralo u stvaranju acquisa za bračnoimovinski režim ${ }^{42}$ ipak, u državama članicama koje sudjeluju u pojačanoj suradnji donijela je ujednačenje pravila o nadležnosti, mjerodavnom pravu te priznavanju i izvršavanju odluka u stvarima bračnoimovinskog režima $s$ prekograničnim elementom. Crpeći iz iskustava država članica u primjeni pravila međunarodnog privatnog prava u predmetima u kojima je potrebno odlučiti $u$ stvarima bračnoimovinskog režima, EU zakonodavac je pri uređivanju pravila Uredbe 2016/1103 krenuo od nekoliko temeljnih pretpostavaka:

- nacionalna uređenja bračnoimovinskih režima počivaju na autonomiji volje, te je stoga poželjno osigurati autonomiju volje bračnih drugova u odnosu na izbor mjerodavnog prava za odlučivanje u stvarima bračnoimovinskih režima u predmetima s prekograničnim elementom,

- pravila o nadležnosti koja kao primarni kriterij koriste kriterij uobičajnog boravišta u koordinaciji s kolizijskopravnim upućivanjem kriterijem uobičajnog boravišta čine funkcionalno jedinstvo ${ }^{43}$ te osiguravaju da sud koji je nadležan za odlučivanje u konkretnom predmetu primjenjuje vlastito pravo,

- ako se o stvarima bračnoimovinskog režima ima odlučiti u postupku razvoda braka ili ostavinskom postupku s prekograničnim elementom, potrebno je omogućiti da sud države članice nadležan za razvod braka ili ostavinski postupak odlučuje i o bračnoj stečevini, što se može ostvariti primjenom pravila o koncentraciji nadležnosti.

40 Pinters, W., Matrimonial Property in Europe, u: Boele Woelki, K.; Scherpe, Miles, J. M. (ur.), The Future of Family Property in Europe, Intersentia, 2011., str. 19-45.; Struycken, A. V. M., Régimes matrimoniaux - blanc d'essai de la codifi cation international du droit international prive, u: A. Borras i drugi (ur.), E Pluribus Unum, Liber Amicorum G. A. L. Droz, Hague/ Boston/London, 1996., str. 445-460. U hrvatskoj pravnoj teoriji vidi Župan, Mirela, Izbor mjerodavnog prava u obiteljskim, statusnim i nasljednim stvarima, Zbornik Pravnog fakulteta Sveučilišta u Rijeci, vol. 33., br. 2., 2012., str. 629-666.

41 Aktivnosti na ovom području započele su donošenjem Zajedničkog programa mjera Komisije i Vijeća za provedbu načela uzajamnog priznavanja odluka u građanskim i trgovačkim stvarima od 30. studenoga 2000., u okviru kojega su identificirane mjere u vezi s usklađivanjem kolizijskih pravila, kao mjere kojima se olakšava uzajamno priznavanje odluka i predviđa izrada instrumenta u stvarima bračnoimovinskih režima. Službeni list Europske unije C 12, 15.1.2001., str. 1.

42 Iz odredbe čl. 20. st. 4. Ugovora o EU proizlazi da će aktima kojima se uspostavlja pojačana suradnja biti obvezane isključivo države članice koje u njoj sudjeluju te oni ne predstavljaju dio acquisa.

43 Usporedi Župan, M., op. cit., str. 663. 
Polazeći od navedenih pretpostavaka, Uredba 2016/1103 se oslanja na autonomiju volje stranaka i u dijelu pravila o nadležnosti koja predviđaju sporazum stranaka o izboru suda u korist države članice mjerodavnog prava ili sudova države članice u kojoj je sklopljen brak. U odnosu na izbor prava mjerodavnog za bračnoimovinski režim nastojalo se osigurati da se pravo koje je izabrano kao mjerodavno primjenjuje na cjelokupnu bračnu stečevinu, neovisno gdje se pojedini dijelovi imovine nalaze ili o kojoj je vrsti imovine riječ. U tom smislu, kao primarni primjenjuje se kriterij uobičajenog boravišta, a podredno državljanstva bračnih drugova.

Unatoč namjeri da se Uredbom 2016/1103 osigura usklađenost pravila o nadležnosti i kolizijskih pravila i tako izbjegnu poteškoće pri odlučivanju o bračnoimovinskom režimu u prekograničnim predmetima, ako se pravila Uredbe 2016/1103 o nadležnosti i mjerodavnom pravu promatraju u kontekstu primjene u predmetima s prekograničnim elementom u kojima bi se u stvarima bračnoimovinskog režima imalo odlučivati u ostavinskom postupku, očigledno je da će pojedina rješenja donijeti određene neželjene učinke.

Primjedbu je tako moguće istaknuti vezano uz izjednačeni položaj preživjelog bračnog druga s drugim sudionicima postupka u odnosu na mogućnost prorogacije nadležnosti na sud države članice čiji je ostavitelj državljanin i čije je pravo izabrao kao mjerodavno za odlučivanje u ostavinskom postupku. Naime, puko upućivanje na primjenu Uredbe 650/2012 o nasljeđivanju ne ostavlja prostora da se povede računa o specifičnom položaju i s tim u vezi, interesima preživjeloga bračnog druga u odnosu na ostale sudionike odnosno nasljednike kod rješavanja u stvarima bračnoimovinskog režima. Premda se u odnosu na tekst Prijedloga Uredbe 2016/1103 u pravnoj teoriji sugeriralo da je taj problem moguće otkloniti tako da se u odredbi čl. 4. Uredbe 2016/1103 predvidi da bi sudovi države članice suda koji u skladu s Uredbom 650/2012 o nasljeđivanju imaju odlučivati o ostavinskom postupku bili nadležni za odlučivanje u stvarima bračnoimovinskog režima isključivo ako bi preživjeli bračni drug na to pristao, ${ }^{44}$ to rješenje nije prihvaćeno. Nekoliko je razloga koje pritom treba uzeti u obzir. U prvom redu, premda bi takvo rješenje vodilo računa o položaju preživjeloga bračnog druga u slučajevima prorogacije nadležnosti sukladno odredbi čl. 5. Uredbe 650/2012 o nasljeđivanju, treba uzeti u obzir da u određenom broju slučajeva neće biti potrebe za takvim zaštitnim mehanizmom, budući da će interesi preživjeloga bračnog druga i ostalih sudionika biti usklađeni. Nadalje, ako se sporazum o prorogaciji nadležnosti koji odgovara interesima preživjeloga bračnog druga ne postigne među sudionicima postupka, preživjelom bračnom drugu ostaje mogućnost sukladno odredbi čl. 6. Uredbe 650/2012 o nasljeđivanju tražiti od suda uobičajenog boravišta ostavitelja u trenutku smrti (arg. ex čl. 4. Uredbe 650/2012 o nasljeđivanju) da odbije postupati ako ocijeni da bi sud države članice čije je pravo ostavitelj izabrao bio u boljem položaju odlučivati. U tom smislu, ne čini se oportunim predloženo rješenje kojim bi se nadležnost suda države članice za postupanje u ostavinskom postupku i odlučivanje u stvarima bračnoimovinskog režima temeljila na pristanku preživjela bračnog druga. Naime, time bi cjelokupno djelovanje režima Uredbe 2016/1103, koji među legitimnim ciljevima ima osiguravanje da se, u velikom broju slučajeva u kojima

44 Grey, J.; Redondo, P. Q., op. cit., str. 11. 
se pitanje podjele bračne stečevine pojavi zbog smrti jednog od bračnih drugova, primjenom pravila o koncentraciji nadležnosti i kolizijskim pravilima postupanje učini pravno sigurnijim, bržim, jednostavnijim i ekonomičnijim za stranke i sud, bilo uvjetovano pristankom preživjela bračnog druga. Izostanak takvog pristanka preživjela bračnog druga imalo bi za posljedicu postupanje različitih sudova država članica pri odlučivanju o nasljeđivanju i u stvarima bračnoimovinskog režima.

Nadalje, primjena pravila o uspostavljanju supsidijarne nadležnosti suda države članice u kojoj se nalazi imovina za odlučivanje o toj imovini (arg. ex čl. 10. st. 2. Uredbe 650/2012 o nasljeđivanju), ako se uobičajeno boravište ostavitelja nalazi u trećoj državi, također može biti problematično, kada je riječ o uspostavljanju nadležnosti za odlučivanje u stvarima bračnoimovinskog režima. Naime, ako se bračna stečevina bračnih drugova, osim u trećoj državi, nalazi i u jednoj od država članica, tim će se pravilom osigurati da sud države članice uspostavi nadležnost, barem za odlučivanje o imovini koja se nalazi u toj državi članici. Pravilo odredbe čl. 10. st. 2. Uredbe 650/2012 ne daje jednoznačan odgovor na pitanje koji će sud biti nadležan za odlučivanje u stvarima bračnoimovinskog režima ako se imovina ostavitelja nalazi u više država članica. Pođe li se od temeljnog cilja Uredbe 2016/1103 da osigura postupanje suda jedne države članice, ništa u odredbi čl. 10. st. 2. Uredbe 650/2012 o nasljeđivanju ne upućuje na to koji bi od sudova država članica bio nadležan odlučiti u stvarima bračnoimovinskog režima. U slučaju da se u jednoj od država članica nalaze pokretnine, a u drugoj nekretnine, za pretpostaviti je da bi u stvarima bračnoimovinskog režima bio nadležan odlučivati sud države članice u kojoj se nalaze nekretnine. Međutim, dosljednim tumačenjem moglo bi se uzeti i da bi svaki od sudova država članica u kojoj se imovina nalazi bio nadležan za odlučivanje o dijelu imovine koja ulazi u bračnu stečevinu, a nalazi se u toj državi članici. Ovakvo rješenje zasigurno ne pridonosi pravnoj sigurnosti niti predvidljivosti u postupanju u odnosu na odlučivanje u stvarima bračnoimovinskog režima. Dvojbeno je bi li u pravnoj literaturi predloženo uvjetovanje primjene odredbe čl. 10. st. 2. Uredbe 650/2012 o nasljeđivanju na uspostavljanje nadležnosti za odlučivanje u stvarima bračnoimovinskog režima pristankom preživjela bračnog druga bilo prikladno. ${ }^{45}$ Premda stoji argument da bi se time izbjegla prisilna primjena pravila o nadležnosti koje predviđa da bi za odlučivanje u stvarima bračnoimovinskog režima bili nadležni sudovi više država članica, ne treba gubiti iz vida da se njime ipak osigurava odlučivanje u režimu Uredbe 2016/1103, dok bi njegova neprimjena potencijalno ostavila prostora da o bračnoj stečevini odlučuje sud treće države uz primjenu kolizijskih pravila koja nisu nužno poznata preživjelom bračnom drugu.

Autonomija volje stranaka pri izboru prava mjerodavnog za odlučivanje u stvarima bračnoimovinskog režima sukladno Uredbi 2016/1103 ograničena je na mogućnost bračnih drugova da upute na primjenu prava uobičajenog boravišta bračnih drugova ili jednog od njih u trenutku sklapanja sporazuma (arg. ex čl. 22. st. 1. t. a.) ili prava državljanstva bračnih drugova ili jednog od njih u trenutku sklapanja sporazuma (arg. ex čl. 22. st. 1. t. b). Premda kriterij uobičajenog boravišta osigurava najbližu vezu bračnih drugova s pravom države članice koje se ima primijeniti, ovdje

45 Grey, J.; Redondo, P. Q., op. cit., str. 13. 
čak ne predstavlja najoptimalniju poveznicu. Naime, samo u slučajevima u kojima bračni drugovi neće mijenjati svoje uobičajeno boravište sve do smrti ostavitelja, primjena odredbe čl. 22. st. 1. t. a Uredbe 2016/1103 u vezi s odredbom čl. 21. st. 1. Uredbe $650 / 2012$ o nasljeđivanju osigurat će da se kao mjerodavno primjenjuje pravo suda države članice koji odlučujući o nasljeđivanju ujedno odlučuje i u stvarima bračnoimovinskog režima. U protivnom, do željene koordinacije ostavinskog postupka i postupka u kojemu se odlučuje o bračnoj stečevini neće doći jer će se, primjerice, razlikovati mjerodavno države članice uobičajenog boravišta bračnih drugova u trenutku sklapanja sporazuma o pravu mjerodavnom za bračnoimovinski režim od uobičajenog boravišta ostavitelja, odnosno bračnih drugova u trenutka smrti. U tom smislu, sporazumijevanje o mjerodavnom pravu za odlučivanje o bračnoimovinskom režimu prema kriteriju državljanstva jednog od bračnih drugova kao nepromjenjivom, a time i stabilnijem kriteriju osigurava da neovisno o eventualnom preseljenju bračnih drugova za života, pravo suda države članice nadležnog za odlučivanje u ostavinskom postupku ujedno bude mjerodavno za odlučivanje u stvarima bračnoimovinskog režima. Međutim, ovo vrijedi samo uz pretpostavku da je kao mjerodavno za odlučivanje u stvarima bračnoimovinskog režima izabrano pravo države članice čiji je državljanin umrli bračni drug. Premda je u pravnoj teoriji iznesen prijedlog da se intervencijom u odredbe Uredbe 650/2012 o nasljeđivanje omogući primjena prava mjerodavnog za odlučivanje u stvarima bračnoimovinskog režima i na odlučivanje o nasljeđivanju, ne čini se primjerenim niti mogućim takvo zadiranje u uspostavljeni režim Uredbe 650/2012 o nasljeđivanju.

Pravila Uredbe 2016/1103 odražavaju spoznaje, koje se kao svojevrstan trend pojavljuju i potvrđuju u novijim europskim instrumentima iz područja pravosudne suradnje, da je potrebno osigurati određenu autonomiju stranaka pri određivanju pravila o nadležnosti i mjerodavnom pravu koje se imaju primijeniti u predmetu s prekograničnim elementom. Naime, postizanje sporazuma o nadležnosti i izboru mjerodavnog prava doprinosi pravnoj sigurnosti i jača povjerenje stranaka. Ujedno, olakšava postupanje sudovima, sprječavanjem tzv. "juriša na sud” kojim stranke žele za sebe osigurati primjenu povoljnijeg prava. ${ }^{46}$ Ipak, analiza usklađenosti pravila o nadležnosti i mjerodavnom pravu Uredbe 2016/1103 s pravilima Uredbe 650/2012 o nasljeđivanju pokazala je da nije moguće postići željenu koordinaciju pravila o nadležnosti niti koordinaciju u primjeni mjerodavnog prava te da će u tom smislu, Uredba 2016/1103 predstavljati izazov za pravne praktičare, osobito u početku njezine primjene.

Iz perspektive provođenja ostavinskih postupaka koje u RH kao povjerenici suda vode javni bilježnici ili sudovi, najprije će se pojaviti pitanje određivanja prekograničnog elementa predmeta, koji nije definiran Uredbom 2016/1103. Stoga će javni bilježnik biti dužan, u svakom pojedinom predmetu, imajući u vidu sudionike u postupku, sud te imovinu bračnih drugova, procijeniti postoji li prekogranični element

46 Usporedi Izvješće Komisije Europskom parlamentu, Vijeću i Europskom gospodarskom i socijalnom odboru o primjeni Uredbe Vijeća (EZ) br. 2201/2003 o nadležnosti, priznavanju i izvršenju sudskih odluka u bračnim sporovima i u stvarima povezanim s roditeljskom odgovornošću, kojom se stavlja izvan snage Uredba (EZ) br. 1347/2000, COM(2014)225 fin., str. 5 . 
predmeta. Potom, kako bi se primijenila pravila o nadležnosti, bit će potrebno utvrditi uobičajeno boravište bračnih drugova. Niti to neće biti bez poteškoća, budući da Uredba 2016/1103 ne donosi kriterije kojima se uobičajeno boravište ima utvrđivati, nego će se biti potrebno osloniti na Preambulu Uredbe 650/2012 o nasljeđivanju te judikaturu Europskog suda u međunarodno obilježenim obiteljskim odnosima. Analiza je pokazala da unatoč pokušaju da se uspostavi režim koji bi u najvećoj mogućoj mjeri osiguravao da sud države članice, pri odlučivanju o nasljeđivanju, donese i odluku o bračnoimovinskom režimu primjenom vlastitog prava, to nije moguće postići u svim predmetima. To u najvećoj mjeri treba pripisati okolnosti da je riječ o područjima kod kojih nije moguće osigurati, makar i ograničenu autonomiju strankama pri izboru mjerodavnog prava, a da se ne vodi računa o prirodi odnosa u pogledu kojega se donose pravila. Konkretno, za ostavinski postupak primarni je kriterij posljednjeg uobičajenog boravišta ostavitelja u trenutku smrti, koji pretpostavlja da je riječ o onoj državi članici gdje se nalazi pretežni dio njegove imovine te nasljednici. Istovremeno, za bračne drugove kriterij uobičajenog boravišta vezan je za državu članicu s kojom su bračni drugovi najbliže povezani, što proizlazi ili iz njihova sporazuma o izboru mjerodavnog prava ili ako nije izvršen izbor, okolnosti da je faktična veza bračnih drugova $\mathrm{s}$ prvim zajedničkim uobičajenim boravištem nakon sklapanja braka postojana te se dade utvrditi. Naime, u odnosu na posljednje zajedničko uobičajeno boravište bračnih drugova moglo bi se prigovoriti da, osobito u slučajevima razvoda braka, zbog propadanja bračne zajednice teško bi bilo utvrditi faktičnu vezu bračnih drugova s državom članicom.

Zaključno, premda će u dijelu postupaka Uredba 2016/1103 olakšati postupanje, kompleksnost uspostavljenih pravila zasigurno će donijeti određene izazove. Primjena Uredbe 2016/1103 u ostavinskim postupcima s prekograničnim elementom u kojima će se odlučivati o bračnoimovinskom režimu traži dobro poznavanje oba europska instrumenta te razumijevanje načina na koji se imaju koordinirano primjenjivati. Zasigurno, ona neće donijeti željeno pojednostavljenje postupaka ako suci i javni bilježnici koji će ih primjenjivati ne steknu potrebne vještine. Uz to, bit će potrebno razmisliti o uklanjanju ograničenja koja u smislu učinkovitog postupanja u hrvatskom pravnom sustavu trenutno predstavlja nemogućnost provedbe uknjižbe odluke o raspodjeli bračne stečevine donesene u ostavinskom postupku kojega provodi javni bilježnik.

Ograničavajući učinak u odnosu na ideju olakšavanja postupanja pri odlučivanju u stvarima bračnoimovinskog režima u ostavinskim postupcima imat će okolnost da će se režim Uredbe 2016/1103 odnositi na 18 država članica. Iz navedenoga proizlazi da će određeni broj država članica predstavljati treće države u smislu njezine primjene te će o tomu trebati voditi računa. RH je među državama članicama koje su prihvatile pojačanu suradnju na ovome području te će svojim iskustvima i spoznajama u primjeni Uredbe 2016/1103 sudjelovati u izgradnji pretpostavaka da se njezina primjena proširi i na države članice koje nisu obuhvaćene pojačanom suradnjom. Koliko su takva očekivanja opravdana pokazat će rezultati koje će polučiti njezina primjena u državama članicama nakon 29. siječnja 2019. 


\section{LITERATURA}

1. von Overbeck, Alfred E., Explanatory Report on the 1978 Hague Matrimonial Property Regimes Convention, The Hague, 1978.

2. Drličková, Klára; Rohová, Iveta, Habitual Residence as a Single Connecting Factor Under the Succession Regulation, u: Scientific Cooperations (ur.), Scientific Cooperations Workshops on Social Sciences, Ankara, Scientific Cooperations, 2015., str. 371-381.

3. Vuković, Đuro; Kunštek, Eduard, Međunarodno građansko postupovno pravo, Zgombić i partneri, Zagreb, 2005.

4. Pinters, Walter, Matrimonial Property in Europe, u: Boele Woelki, K., i Scherpe, Miles, J. M. (ur.), The Future of Family Property in Europe, Cambridge, Intersentia, 2011., str. 19-45.

5. Struycken, Antoon Victor Marie, Régimes matrimoniaux - blanc d'essai de la codifi cation international du droit international prive, u: A. Borras i drugi (ur.), E Pluribus Unum, Liber Amicorum G. A. L. Droz, Hague/Boston/London, M. Nijhoff Publishers, 1996., str. 445-460.

6. Grey, Jacqueline; Redondo, Pablo Quinzá, Stress-testing the EU Proposal on Matrimonial Property Regimes: Co-operation between EU private international law instruments on family law and successions, str. 1-37., dostupno na: http://www.familyandlaw.eu/ tijdschrift/fenr/2013/11/FENR-D-13-00008.

7. Martiny, Dieter, Die Kommissionsvorschläge für das internationale Ehegüterrecht sowie für das internationale Güterrecht eingetragener Partnerschaften, IPRax, vol. 31., br. 5., 2011., str. 437-358.

8. Pintens, Walter, Applicable law in the Proposal for Regulation on matrimonial property law, u: Successions and matrimonial property regimes in Europe: notarial solutions, Société de législation comparée, Paris, 2014., str. 85-90.

9. Poretti, Paula, Nadležnost, nadležna tijela i postupci prema Uredbi (EU) br. 650/2012 o nasljeđivanju, Zbornik Pravnog fakulteta Sveučilišta u Rijeci, vol. 37., br. 1., 2016., str. 561-587.

10. Župan, Mirela, Izbor mjerodavnog prava u obiteljskim, statusnim i nasljednim stvarima, Zbornik Pravnog fakulteta Sveučilišta u Rijeci, vol. 33., br. 2., 2012., str. 629-666.

Pravni akti

1. Izvješće Komisije Europskom parlamentu, Vijeću i Europskom gospodarskom i socijalnom odboru o primjeni Uredbe Vijeća (EZ) br. 2201/2003 o nadležnosti, priznavanju i izvršenju sudskih odluka u bračnim sporovima i u stvarima povezanim s roditeljskom odgovornošću, kojom se stavlja izvan snage Uredba (EZ) br. 1347/2000, $\operatorname{COM}(2014) 225$ fin.

2. Konvencija od 14. ožujka 1978. o mjerodavnom pravu za bračnoimovinski režim, stupila na snagu 1. rujna 1992., dostupno na: http://www.hcch.net/index_ en.php?act $=$ conventions. status\&cid $=87$.

3. Prijedlog Uredbe Vijeća o nadležnosti, mjerodavnom pravu te priznavanju i izvršenju odluka u stvarima bračnoimovinskih režima, $\operatorname{COM}(2011) 126$.

4. Provedbena Uredba Komisije (EU) br. 1329/2014 od 9. prosinca 2014. o uspostavi obrazaca iz Uredbe (EU) br. 650/2012 Europskog parlamenta i Vijeća o nadležnosti, mjerodavnom pravu, priznavanju i izvršavanju odluka i prihvaćanju i izvršavanju javnih isprava u nasljednim stvarima i o uspostavi Europske potvrde o nasljeđivanju, Službeni list EU, L 359, 16.12.2014.

5. Uredba(EU) br. 650/2012 Europskog parlamenta i Vijeća od 4. srpnja 2012. o nadležnosti, mjerodavnom pravu, priznavanju i izvršavanju odluka i prihvaćanju i izvršavanju javnih isprava u nasljednim stvarima i o uspostavi Europske potvrde o nasljeđivanju, Službeni 
list EU, L 201, 27.7.2012, str. 107-134. Posebno izdanje na hrvatskom jeziku, poglavlje 19, vol. 010.

6. Uredba Vijeća (EZ) br. 2201/2003 od 27. studenoga 2003. o nadležnosti, priznavanju i izvršenju sudskih odluka u bračnim sporovima i u stvarima povezanim s roditeljskom odgovornošću, kojom se stavlja izvan snage Uredba (EZ) br. 1347/2000, Službeni list EU, L $338,23 / 12 / 2003$.

7. Uredba Vijeća (EU) br. 1259/2010 od 20. prosinca 2010. o provedbi pojačane suradnje u području prava primjenljivog na razvod braka i zakonsku rastavu, Službeni list EU, L $343,29.12 .2010$.

8. Uredba (EU) br. 1215/2012 Europskog parlamenta i Vijeća od 12. prosinca 2012. o nadležnosti, priznavanju i izvršenju sudskih odluka u građanskim i trgovačkim stvarima (preinačena), Službeni list EU, L 351, 20.12.2012.

9. Uredba Vijeća (EZ) br. 4/2009 od 18. prosinca 2008. o nadležnosti, mjerodavnom pravu, priznavanju i izvršenju sudskih odluka te suradnji u stvarima koje se odnose na obvezu uzdržavanja, Službeni list EU, L 7, 10.1.2009.

10. Uredba (EZ) br. 593/2008 Europskog parlamenta i Vijeća od 17. lipnja 2008. o pravu koje se primjenjuje na ugovorne obveze, Službeni list EU, L 177, 4.7.2008.

11. Uredba (EZ) br. 864/2007 Europskog parlamenta i Vijeća od 17. srpnja 2007. o pravu koje se primjenjuje na izvanugovorne obveze, Službeni list EU, L 199/40, 31.07.2007.

12. Uredba (EU) Vijeća 2016/1103 od 24. lipnja 2016. o provedbi pojačane suradnje u području nadležnosti, mjerodavnog prava te priznavanja i izvršenja odluka u stvarima bračnoimovinskih režima, Službeni list EU, L 183/1, 8.7.2016.

13. Uredba Vijeća o provedbi pojačane suradnje u području nadležnosti, mjerodavnog prava te priznavanja i izvršenja odluka u stvarima bračnoimovinskih režima, međuinstitucijski predmet: 2016/0059 (CNS), JUST CIV 70, 30.5.2016. (OR.en)

14. Ugovor o funkcioniranju Europske unije (pročišćeni tekst), Službeni list EU, C 326, 26.10.2012.

15. Zakon o nasljeđivanju, NN, br. 48/03., 163/03., 35/05., 127/13., 33/15.

16. Zakon o provedbi Uredbe (EU) br. 650/2012 Europskog parlamenta i Vijeća od 4. srpnja 2012. o nadležnosti, mjerodavnom pravu, priznavanju i izvršavanju odluka i prihvaćanju i izvršavanju javnih isprava u nasljednim stvarima i o uspostavi Europske potvrde o nasljeđivanju, NN, br. 152/14.

17. Zelena knjiga o sukobu zakona u stvarima koje se tiču bračnoimovinskih režima, uključujući pitanja nadležnosti i priznanja, COM(2006) 400 fin.

18. Zajednički program mjera Komisije i Vijeća za provedbu načela uzajamnog priznavanja odluka u građanskim i trgovačkim stvarima, od 30. studenoga 2000., u okviru kojega su identificirane mjere u vezi s usklađivanjem kolizijskih pravila, kao mjere kojima se olakšava uzajamno priznavanje odluka i predviđa izrada instrumenta u stvarima bračnoimovinskih režima, Službeni list EU, C 12, 15.1.2001.

Sudska praksa Europskoga suda

1. Presuda od 8. studenog 2005. godine, predmet C-443/03 - Leffler, ECLI:EU:C:2005:665

2. Presuda od 22. prosinca 2010. godine, predmet C-497/10 PPU - Mercredi, ECLI:EU:C:2010:829

3. Presuda od 2. listopada 2003. godine, predmet C-148/02 - Garcia Avello, ECLI:EU:C:2003:539

4. Presuda od 16. srpnja 2009. godine, predmet C-168/08 - Hadadi, ECLI:EU:C:2009:474. 
Summary

\title{
DECIDING ON MATTERS OF MATRIMONIAL PROPERTY IN THE PROCEEDINGS FOR SUCCESSION UNDER REGULATION 2016/1103 ON MATRIMONIAL PROPERTY REGIMES
}

\begin{abstract}
Council Regulation (EU) 2016/1103 of 24 June 2016 implementing enhanced cooperation in the area of jurisdiction, applicable law and the recognition and enforcement of decisions in matters of matrimonial property regimes (hereinafter: Regulation 2016/1103) provides for uniform rules which should facilitate delivering of judgments concerning matrimonial property in cross-border disputes in 18 Member States which established enhanced cooperation between themselves in the area of the property regimes of international couples. The application of the Regulation 2016/1103 should contribue to the application of other european instruments in the field of european family law in divorce and succession proceedings. The paper presents rules on jurisdiction and applicable law under the Regulation 2016/1103 which should be applied in proceedings concerning matrimonial property regimes. Application of the provisions of Regulation 2016/1103 on jurisdiction and applicable law in proceedings for succession will be analyzed. The paper elaborates on certain potentially problematic solutions and open issues revealed through interpretation of provisions of Regulation 2016/1103 which could cause doubts and uncertainties for the court and public notaries. Possible solutions which could remove difficulties and insufficiencies in the application of the Regulation 2016/1103 will be suggested.
\end{abstract}

Keywords: succession, matrimonial property regime, jurisdiction, applicable law, spouse.

Zusammenfassung

\section{ENTSCHEIDUNG ÜBER ANGELEGENHEITEN DES EHELICHEN VERMÖGENS IM ERBRECHT NACH DER VERORDNUNG NR. 2016/1103 IN FRAGEN DES EHELICHEN GÜTERSTANDS}

Die Verordnung (EU) 2016/1103 des Rates vom 24. Juni 2016 zur Durchführung einer Verstärkten Zusammenarbeit im Bereich der Zuständigkeit, des anzuwendenden Rechts und der Anerkennung und Vollstreckung von Entscheidungen in Fragen des ehelichen Güterstands (nachstehend: Verordnung 2016/1103) ermöglicht eine einheitliche Regelung, welche die Erbringung von Urteilen über Ehegüter bei grenzüberschreitenden Streitigkeiten in 18 Mitgliedstaaten erleichtern sollte, die 
eine verstärkte Zusammenarbeit im Bereich der Eigentumsregelungen internationaler Paare erlaubt. Die Anwendung der Verordnung 2016/1103 sollte zur Anwendung anderer europäischer Rechtsakte im Bereich des europäischen Familienrechts in Scheidungs- und Nachfolgeverfahren beitragen. Dieser Artikel enthält Vorschriften über die Zuständigkeit und das anwendbare Recht nach der Verordnung 2016/1103, die in Verfahren betreffend Ehescheidungsregelungen anzuwenden sind. Die Anwendung der Bestimmungen der Verordnung 2016/1103 über die Zuständigkeit und das anwendbare Recht im Erbrecht wird analysiert. Der Artikel befasst sich mit bestimmten potenziell problematischen Lösungen und offenen Fragen, die durch die Auslegung der Bestimmungen der Verordnung 2016/1103 offenbart werden und die Zweifel und Ungewissheiten für das Gericht und die Notare hervorrufen könnten. Mögliche Lösungen, die Schwierigkeiten und Unzulänglichkeiten bei der Anwendung der Verordnung 2016/1103 beseitigen könnten, werden vorgeschlagen.

Schlüsselwörter: Erbfolge, ehelicher Güterstands, Gerichtsbarkeit, anwendbares Recht, Ehegatte.

Riassunto

\section{DECISIONI CIRCA I RAPPORTI PATRIMONIALI TRA CONIUGI NEI PROCEDIMENTI SUCCESSORI IN FORZA DEL REGOLAMENTO 2016/1103 SUI REGIMI PATRIMONIALI TRA CONIUGI}

Con l'entrata in vigore del Regolamento (UE) 2016/1103 del Consiglio del 24 giugno 2016 che attua la cooperazione rafforzata nel settore della competenza, della legge applicabile, del riconoscimento e dell'esecuzione delle decisioni in materia di regimi patrimoniali tra coniugi (in avanti: Regolamento 2016/1103) nei diciotto stati membri che prendono parte alla cooperazione rafforzata, applicando tali regole comuni, verranno agevolate le decisioni nelle questioni afferenti i rapporti patrimoniali tra coniugi aventi elemento di transnazionalità. Inoltre, si prevede mediante la sua applicazione che negli stati membri divenga più facile anche l'applicazione di altri strumenti europei nell'ambito del diritto europeo della famiglia nei procedimenti di divorzio ed in quelli successori. Nel lavoro verranno illustrate le regole del Regolamento 2016/1103 sulla competenza e sul diritto applicabile nei procedimenti nei quali si decide dei rapporti patrimoniali tra coniugi. Si esaminerà l'applicazione delle regole del Regolamento 2016/1103 sulla competenza e sul diritto applicabile nei procedimenti successori con elemento transfrontaliero nei quali si applica il Regolamento 650/2012 in materia di successioni. Si rileveranno eventuali questioni controverse che sorgono nell'interpretare le regole del Regolamento 2016/1103, che potrebbero sollevare dubbi e lacune per le corti ed i notai in occasione della risoluzione dei rapporti patrimoniali nei procedimenti dove si decida di successioni. 
In conclusione si suggeriranno possibili soluzioni con le quale potrebbero venire superate difficoltà e lacune nell'applicazione pratica del Regolamento 2016/1103.

Parole chiave: successione, regimi patrimoniali tra coniugi, competenza, diritto applicabile, coniuge. 